\title{
THE INFLUENCE OF INNOVATIVENESS ON THE WORK PERFORMANCE OF PHYSICSTEACHERIN THE STATE SENIOR HIGH SCHOOL AT BENGKULU PROVINCE
}

\author{
Connie', Arieldo Meizul Zuki²

\begin{abstract}
1,2 Department of Education, Faculty of Education, University of Bengkulu, Indonesia Email: 'connienurmatias@yahoo.com 2flameeizell8@gmail.com
\end{abstract}

\begin{abstract}
This research objective was to analyze the influence of the professional competence, work motivation, and innovativeness of physics teachers on the work performance of physics teachers in the state senior high school at Bengkulu province. This research was conducted by surveying physics teachers in the state high school at Bengkulu province. A sample of 90 teachers of physics was selected using a simple random sampling technique. Data were analyzed using the "path analysis method" with Microsoft Excel and SPSS17 as research's computing tools. The results concluded that there are direct, positive, and significant influences of professional competency, work motivation, and innovativeness of physics teachers toward the work performance of the physics teacher. Moreover, the professional competency and the work motivation of the physics teacher have an indirect, positive, and significant influence on the work performance of physics teachers through the innovativeness of the physics teacher itself.
\end{abstract}

Keywords: innovativeness; work performance of the physics teacher.

\section{INTRODUCTION \\ Background Issues}

Education can be seen as trustworthy to prepare men to face the changes that occur in society. Education is not static but dynamic. So it needs improvement continuously. The problem faced today is the low quality of education due to the low quality of physics teachers. Results of Initial Competency Test on National scale (UKA) in 2012 for high school in physics subjects have absorptive 47.52. It shows that high school teachers' ability is still low in understanding aspects of the curriculum and mastery of the subject matter of physics teachers. The teachers' knowledge in methods of teaching is not adequate also (National Education, 2012). Judging from the applied learning by teachers in the field, there is a tendency for the teaching and learning process to happen classically in the class. It just depends on the textbook as teaching methods that emphasize memorization instead of understanding the concepts. Here, teachers as a learning center. The development of process skills to students is infrequent. Teachers are less capable of teaching practices that lead to process skills.

Its impact on the learning outcomes of students, particularly in physics subjects, is not maximized. Learning physics has not been a favorite for students, even very burdensome students. It impressed scary in terms of our country's need for young people to understand the physics and choose the field of physics to advance technology that is still far behind countries in Asia such as Japan, Korea, and Taiwan. Physics is the science underlying the technology. The students need to inculcate a sense of joy in learning physics. The ability of the teacher to manage an exciting learning physics is desirable. Then, the performance of the physics teacher needs to investigate. The management of learning physics by what expected, as stated in the objectives of learning physics ?

A physics teacher's performance has not kept pace with what expected in the learning objectives of physics. It caused by physics teachers have not been up to 
apply the principles of science learning in teaching physics. The performance of the physics teacher is a very decisive factor for the quality of education/learning physics that will have implications on the quality of the output of education after finishing school. The quality of physics teacher performance will largely determine the quality of the education/learning physics. It caused by the teacher is the man who the most direct contact with students in the educational process at the school institution-efforts to improve continuously the quality of learning to be a professional attitude as educators. Develop innovative things that need to do physics teachers to improve the quality of education and learning physics. Thus, creativeness and innovativeness will be crucial things (UharSuharsaputra, 2011). Speed to accept innovation or called innovativeness is the degree or the degree to which an individual or a particular receiver unit receives a new idea or innovation relatively early compared with other members (Rogers, 1995: 264-266). Innovation in the form of the method may result in improvement, improve the quality of education, and tools or new ways of solving problems encountered in educational activities.

Keith Davis (1994: 484) argues that many factors that can influence performance are; 1) Motivation factor formed from an employee attitude in the face of the work situation. 2) Ability Factors (Ability) consists of potential ability (IQ) and the ability of reality (Knowledge + Skill). According to Robert Kreitner and Angelo Kinicki (2001: 205), motivation is a psychological process that generates and directs behavior to the achievement of goals or goal-directed behavior. Gibson (2000:87) said that work motivation closely linked to behavior and performance. Work motivation directed to achieve the goal. The causal relationship between work motivation and performance presented byMangkunegara (2005:67) that the factors influencing the performance are the work motivation that formed from an employee attitude in the face of the work situation. Work motivation is a condition that drives self-directed employees to achieve organizational goals. Mental attitude is a mental state that encourages employees to strive for self-employment to maximum performance. Employees will be able to achieve maximum performance if he is highly motivated. Performance has a causal relationship with competence. Performance is the skills, behaviors, attitudes, and actions. Competence shows characteristics of knowledge, skills, attitudes, and experience to do the job (Wirawan, 2009:9-10).

Johnson (1980:12) describes the components of professional competence contain competencies that related to professional education, such as mastery of theory, principles, strategies, and techniques of education and teaching. According to some opinions on this research to reveal whether physics teacher

1. s' professional competence, work

2. motivation

3. , and innovativeness influence

4. the performance of physics teachers in the State High School in Bengkulu Province.

\section{RESEARCH METHODS}

The method used in this research is a survey with the quantitative research approach. The type of survey research focused on expressing a causal relationship between variables. The analytical techniques used to examine the causal relationship is path analysis. This research population is all of the physics teachers ( who have worked at least three years and a minimum S1 Physical Education) in the state high school in Bengkulu Province. The affordable population numbered 177 people and following the characteristics of a total of 122 people. The sample size of 90 people determined by Slovin the equation developed (Sevilla, 1993: 161-162) and by simple random sampling technique.

The reliability of physics teacher performance, work motivation, and innovativeness calculate by using the Cronbach Alpha formula. The result of the calculation on the reliability coefficient at the physics teacher performance instruments is obtainedr count $=0.920$. The result of the calculation on the reliability coefficient at the work motivation instrument obtained $r$ count $=0.903$. It can conclude that the instrument used to 
measure the four variables implemented in this research is well worth it.
RESULTS AND DISCUSSION

$\varepsilon_{3}=0.93 \quad \varepsilon_{4}=0.84$

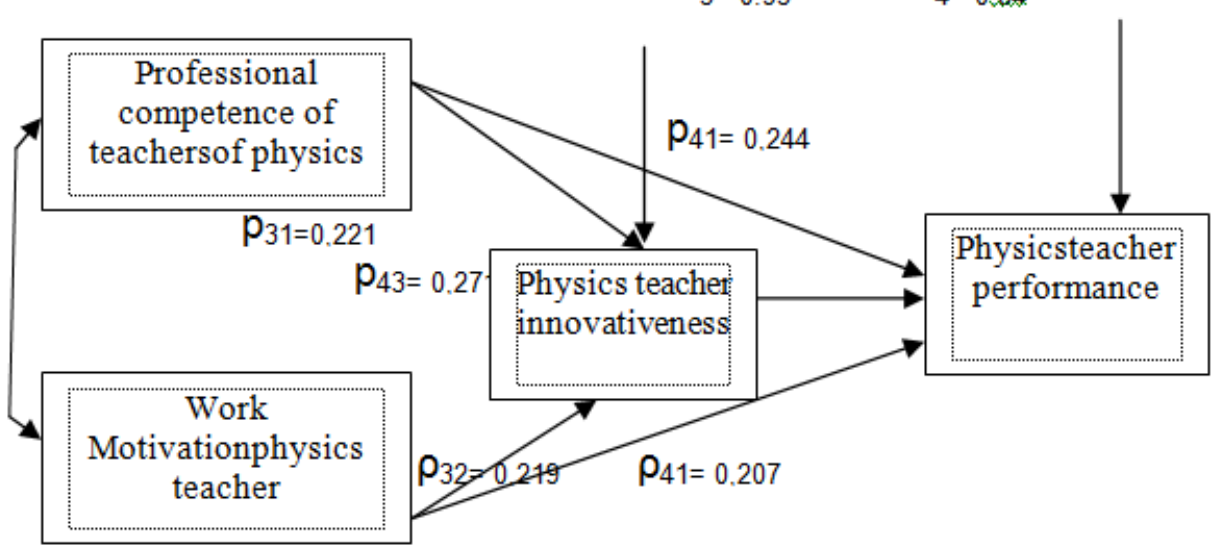

Figure 1. Empirical modelimagescausal relationshiplnterSub-structural 1 and2.

The relation model empirically shows that there are five significant path coefficients on $a=0.05$. These have Sig $<a$ $=0.05$. So, the path coefficients between variables of professional competency of physics teacher $(X 1)$, the motivation of physics teachers (X2), and innovativeness of physics teacher (X3) on the performance of physics teacher (X4) is significant. It means the theoretical model of causal by the empirical model. Thus, it can conclude that the professional competence, work motivation, and innovativeness have a direct positive influence on the performance of physics teacher. Path analysis model also showed an indirect positive influence of professional competence and work motivation on the performance of physics teachers through the innovativeness of physics teachers. Thus, innovativeness is an intermediary or intervening variable of professional competence and work motivation of physics teachers.

\section{Discussion}

The first hypothesis testing results indicate that professional competence has a direct, positive, and significant influence on the physics teacher's performance. It is indicated by the path coefficient $\rho_{41}=0.244$. Thus, the professional competence of physics teachers is the most crucial variable in improving the physics teacher's performance. These results indicate that professional competence has a direct positive influence on the ups and downs variable of physics teacher performance. It supports the opinion of Keith Davis (1994: 484) and the results of Kingkin research (2011) that the physics teacher will be able to achieve maximum performance if it has the ability of professional competence in this regard.

The research results found that the value of the physics teacher's professional competence is to be from enough to less category $(<58.27)$. This value is owned by approximately $65.6 \%$ in the state high school physics teacher in Bengkulu province. How does physics teacher in this category capable of teaching well to students? It is in line with Johnson (1980: 12) opinion about the professional component of teacher competence. It said that the competence related to professional education includes mastery of theory, principles, strategies, and techniques of education and teaching. If physics teacher have a low professional component, it means mastery of theory, principles, strategies, and techniques of education and teaching is also low. Naturally, physics teachers in this category have not managed to make a favorite subject for physics because physics teacher is the most direct contact with students in the learning process of physics.

To improving the professional competence of physics, teachers should be considered an essential indicator in the instrument that measures the professional competence of physics teachers. It needs 
to determine the level of understanding of physics concepts on physics teachers and physics teaching methodologies that are still problematic or misconceptions occur. Development of Professional competence of physics teacher can conduct through advanced study, educational professionalism as Professional Teacher Education (PPG), PLPG, workshops, and others.

Facts, conformity with the research findings, indicate that the professional competence of physics teacher has a direct positive influence on the performance of physics teachers. The professional competence of the physics teacher is still low cause its performance not maximized. Still, open space physics teachers improve performance through increased professional competence to improve the quality of processes and outcomes of learning physics.

The second hypothesis testing results show that work motivation has a direct, positive, and significant influence on the performance of the physics teacher. It indicated by the value of the path coefficient, $\rho_{42}=0.207$. Thus, the work motivation of the physics teacher variable is crucial in improving the physics teacher's performance. The results support the research of Pranawa (2011).

In line with the opinion of James $M$. Higgins in Uhar (2012), it suggests the performance of a person related to a variety of factors. It can influence both internal inherent in the individual and which are external from the work environment. Performance and motivation is something that continuously interacts. Performance is a manifestation of behavioral dimensions, while work motivation is the internal dimension of a person's behavior. Descriptive analysis of the work motivation data obtained an average score $=129.58$. If the average score is a divide with the ideal score (135) and multiplied by 100 , an average score of work motivation can classify in a good category (96). Work motivation is not to be enabled to maximize the performance of physics teachers, mainly related to the learning process of physics.

The third hypothesis testing results show that the innovativeness has a direct, positive, and significant influence on the performance of the physics teacher indicated by the value of the path coefficient $\rho_{43}=0.271$. Thus, innovativeness is the most critical variable in improving the performance of the physics teacher. This result is consistent with the results of Sofyan Iskandar research (2012) that teacher performance is influence by the innovativeness of $20.12 \%$. In line with UharSuharsaputra (2012) opinion, the changes occur in public either input or the environmental community, as a whole demand on increasing the ability of teachers to perform their duties. Physics teachers need to develop new ways to improve the quality of student learning.

The results showed that the value of the path coefficient, $\rho_{43}$ is 0.271 . Descriptive analysis of research data obtained from the average score of innovativeness of physics teachers in the state high school in Bengkulu Province at 134.65. Moreover, $53.4 \%$ of physics teachers' innovativeness is an average and above average in good category (86). Accordance with the facts on the field, physics teacher who has high innovativeness will make innovations and continuously adjust their lesson with the changes or dynamics in society that influence his performance.

The fourth hypothesis testing results indicate that the professional competence of physics teachers has a direct, positive, and significant influence on physics teacher innovativeness indicated by the value of the path coefficient $\rho_{31}=0.221$. Thus, the professional competence of teachers of physics is an essential variable in improving the innovativeness of physics teachers. Performance has a causal relationship with competence (Wirawan, 2009). So, the professional competence of physics teachers needs to develop because of not only as a function of performance, but professional competence is also a function of innovativeness indicated by the path coefficient $\rho_{41}=0.244$ and $\rho_{31}=0.221$.

The model of professional competence path analysis showed that a direct positive influence on the performance of physics teachers and indirect positive influence is through innovativeness. Innovativeness variable serves as an intermediary variable or intervening variable. It means that an 
increase in the variable of professional competence by increasing or accompanied by increased innovativeness physics teachers will provide an even more significant impact on the performance of physics teachers indicated by the total value of the path coefficient $=0.492$.

Research data indicate that the average professional competence of physics teachers is still low, with mastery $<58.27$ that held by approximately $70 \%$ of State High School physics teachers in the province of Bengkulu. A low value of professional competence will positively influence physics teacher innovativeness, especially in the learning process of physics. Components of the professional competence of teachers, according to Johnson (1980), understand the structure, concepts, principles, and methodology of physics science is still low. How could the physics teacher improvise by learning innovatively? To create learning to improve innovativeness can be quickly done by physics, teachers who have high professional competence. The improvement of physics teachers' professional competence needs to be to increased innovativeness and improve the performance of physics teachers.

The fifth hypothesis testing results show that work motivation has a direct, positive, and significant influence on physics teacher innovativeness indicated by the value of the path coefficient, $\rho_{32}=$ 0.219 . Thus, the motivation of physics teachers is an essential variable in improving the innovativeness of physics teachers. The result of this research is consistent with the results of the Arientje Dimpundus research. $13.03 \%$ variation of innovativeness caused by work motivation. Besides this, this research is in line with the theory proposed by Koontz (1996: 15), which states the role of work motivation is essential to encourage teachers to make innovation in order to manipulate the physics of learning and adapting to environmental demands and changes. The high working motivation of physics teachers will emerge and increase creativeness and innovativeness.

Based on the theoretical and empirical models on path analysis, the research results show that work motivation has a direct positive and significant influence on the performance of physics teachers. It also has an indirect, positive, and significant influence on the performance of the physics teacher through innovativeness. Thus, the innovativeness is an intermediate variable or intervening variable of work motivation on the physics teacher's performance. Improving work motivation through increasing innovativeness will significantly influence the performance of physics teachers, as indicated by the total value of the path coefficient $=0.490$. Accordance with the facts on the field that the physics teacher who has a high motivation to work would be easy to make innovations in learning. So, it impacts on the innovativeness of physics teacher and ultimately on performance.

\section{CONCLUSIONS AND RECOMMENDATIONS}

Based on research

1. , the professional competence of physics teachers has a direct, positive, and significant influence on the performance of physics teachers. It means that the high professional competence of physics teachers will improve the performance of physics teachers in the State High School in Bengkulu Province.

2. Work motivation has a direct, positive, and significant influence on the performance of the physics teacher. It means that physics teachers' high work motivation will improve the performance of physics teachers in the State High School in Bengkulu Province.

3. Innovativeness has a direct, positive, and significant influence on the performance of the physics teacher. It means that high innovativeness will increase the performance of physics teachers in the State High School in Bengkulu Province.

4. The professional competence of teachers of physics has a direct, positive, and significant influence on the innovativeness of physics teachers. It means that physics teachers' high professional competence will increase the innovativeness of physics teachers on their duties and responsibilities in the high schools in the Bengkulu Province. 
5. The work motivation of physics teachers has a direct, positive, and significant influence on the innovativeness of physics teachers. It means that the high work motivation of physics teachers will improve the innovativeness of physics teachers in the State High School on their duties and responsibilities in Bengkulu Province.

Based on the research results, discussions and conclusions that have described the suggestions can be put forward especially for physics teacher and other stakeholders such as principals, the Local Government through the Department of National Education, and other educational researchers that how important to improve the professional competence of teachers, teachers' work motivation and innovativeness continuously in order to improve performance. So it will impact on the quality and process of education and learning.

\section{REFERENCES}

Davis, Keith.Organizational Behavior.New York: McGraw Hill, 1994.

Dimpundus, Ariantje. "The motive forward, creativity, and learning innovativeness mathematics and science teachers in high schools Manado." http://isjd. WWII. Lipi/Admin/journal/8307232240. pdf(accessed September 3, 2011).

Gibson, James L, John M. Ivancevich, and James H. Donnely. Organization. Boston: McGraw Hill Companies Inc, 2006.

Heller, Robert. Motivating People. London: Dorling Kindersley, 1998.

Iskandar, Sofyan. "Study of correlation between the ability to manage conflict, innovation, and attitudes toward the teaching profession with the teacher learning ability".http://isjd.pdii.lipi.go.id/ admin/ journal/9207171128. pdf. (accessed July 3, 2012).
Johnson, Charles E. Answer to

Some Basic Question about

Teacher Competencies and Competency-Based Education. New York: Mc Graw Hill, 1980.

Kingkin. "The influence of achievement motivation and competence of the teaching profession on teacher performance in the DistrictJunior High

SchoolKutowinangunKebumen".htt $\mathrm{p}: / / \mathrm{mm}$.unsoed.ac.id/id/ content/impact-achievementmotivation-and-competence of the teaching profession-teacherperformance-SMP-country. (accessed September 3, 2011).

Koontz. Management. 2-edition. Jakarta : Erlangga, 1996.

LawNumber20Year2003

onNationalEducationSystem.

Law Numberl4of 2005 on the Duty sand Obligations of Teachers.

Mangkunagara, Anwar P. Performance Evaluationof Human Resources.Bandung: PT. RefikaAditema,2006.

Pranawa. "The Effect of Work Motivation, LeadershipPrincipal,

Occupational and EnvironmentalPerformance AgainstJuniorAndSenior High SchoolTeacherinBanjarnegara". http://mm.unsoed. ac.id/en/content/impactmotivation-leadership-work-schoolhead-and-environment-work-forperformance teacher. (accessed September 3, 2011).

Rogers, Everett M. Diffusion of Innovation. New York: The Free Press, 1995

Sagala, Syaiful. Strategic Management in education Quality Improvement.Bandung: Alfabeta, 2010. 
Stuart-Kottze, Robin. Performance.

London: Prentice-Hall, 2006.

Sudjana,

RegressionandCorrelationAnalysisTe chniquesfortheresearcher.Bandung:T arsito, 1992.

Sevilla, Consuelo.Methods of research administration. Jakarta: UI, 1993.

Suharsaputra, Uhar. "Development ofTeacherPerformance".http//uhars putra. WordPress. com(accessed July 3,2011 ).

Sutopo. "Contribution SubjectsPhysics inCharacter Education".http://www. google.co.id/url.

laccessed December 3, 2011).

The Ministry of Education and Culture. PreliminaryCompetencyTestResultsIn 2012.Jakarta: the ministry of Education and Culture, 2012.

Wibowo.performance management. Jakarta: Eagle Press, 2010.

Wirawan.Performance Evaluation of Human Resources, Theory, ApplicationsandResearch. Jakarta: Salembafour,2009. 